\title{
A NOTE ON THE ECOSYSTEM HEALTH OF A GLACIER-FED RIVER PINDER FROM CHAMOLI GARHWAL, UTTARAKHAND
}

\author{
K L Bisht ${ }^{1}$, A K Dobriyal ${ }^{2}$ and H R Singh ${ }^{3}$ \\ ${ }^{1}$ Government Postgraduate College, Vikasnagar Dakpatthar-248198, Dehradun \\ ${ }^{2}$ Department of Zoology, H N B Garhwal University Campus, Pauri Garhwal -246001, Uttarakhand \\ ${ }^{3}$ Former Vice Chancellor, Allahabad University, 3/33, Shradhapuri, Meerut
}

Corresponding Author Email Id: anoopkdobriyal@ rediffmail.com

Received: 23.08.2019; Revised: 15.09.2019; Accepted: 12.10.2019

(C)Society for Himalayan Action Research and Development

\begin{abstract}
The paper deals with a summarized account of ecological characteristics and biological productivity of river Pinder which is well known for its water quality conducive for the most important schizothoracine fishery of Uttarakhand. It was observed that the low water temperature and clarity of water favours good populations of phytobenthos and macrozoobenthos which in their turn supports the population quality of fishes. Overall 32 plankton species, 23 macrozoobenthic and 24 fish species were recorded.
\end{abstract}

Keywords: River, Pinder, Plankton, Benthos, Fish

\section{Introduction}

Pinder is one of the important glacier-fed streams of Garhwal Himalaya which originates from Pindari glacier in latitude $30^{\circ} 5^{\prime}$ and longitude $80^{\circ}$ 1 ' at an elevation of about $3810 \mathrm{~m}$ (Fig 1). At Karnprayag it joins with the river Alananda in latitude 30o 15' 43'" and longitude 79o 15' 28", (720m). Health of an ecosystem depends upon its water characteristics and biological productivity. The most important ecological driver is the temperature of system which restricts the growth of plants and metabolism in fishes.(Bisht et.al. (2005). Apart from this the change in water temperature also stimulates spawning in fishes (Singh et.al., 1985). Riverine resources of Garhwal region are extensively studied by different workers for their ecological characteristics. Some important contributors are Badola and Singh (1981), Dobriyal and Singh (1981,1987, 1988), Dobriyal et.al. (1983, 1991, 1992, 1993, 1999, 2002, 2009, 2011), Dobriyal (1985, 1991, 2003, 2006), Nautiyal (1985), Dobriyal and Kumar (1988), Sharma (1991), Khanna et.al. (1992,1993), Kumar and Dobriyal

(1992,1996,1999), Dobriyal and Joshi (1993), Dobriyal and Kotnala (1999 and 2005), Balodi et.al. (2004), Nautiyal et.al. (2004), Gusain and Gusain (2005), Kumar et.al. (2006), Rautela, et.al. (2009), Dobriyal and Dobriyal (2015), Katoch et.al. (2015), Koshal et.al. (2016), Bahuguna and Dobriyal (2018), Goswami and Dobriyal (2018) and Sagir et.al. (2018). Present study is an addition to knowledge on the health characteristics of Pinder river.

\section{Material and Methods}

The study was conducted for 24 months during 1981-82 in the river Pinder at Karnprayag. Physico-chemicalm parameters were studied by the standard methods (Welch, 1948 and APHA, 1975). Biological parameters (Plankton and Macrozoobenthos) were studied as per standard methods (Welch, 1952; Ward and Whipple, 1966). Fishes were identified with the help of Day fauna (1889). 


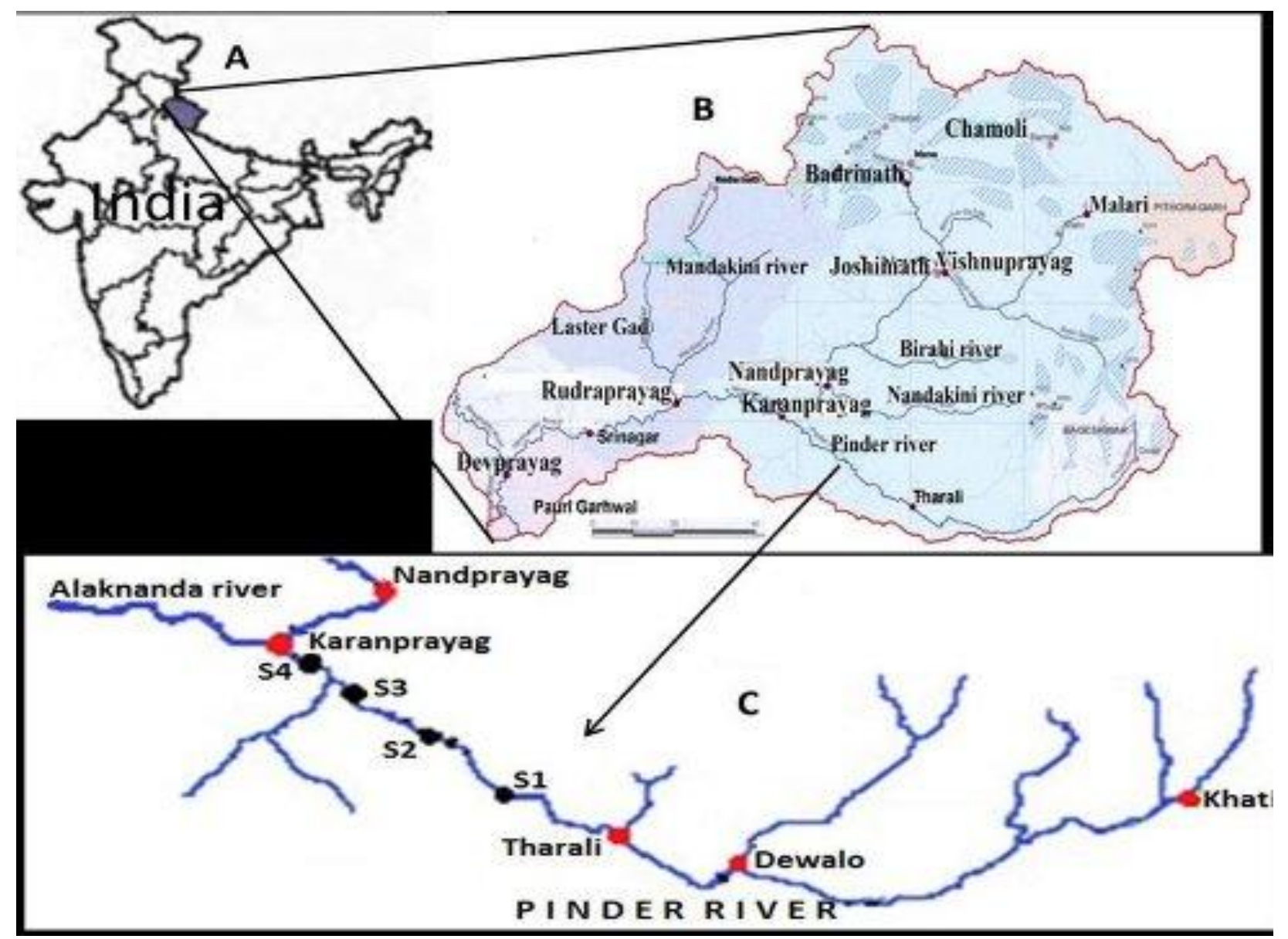

Fig 1 : Location of river Pinder (Courtsey: researchgate.net) and landing sites

\section{Results and Discussion}

The meteorological data and ecological quality of the river Pinder is presented in Table 1.

Summary of biotic profile of the stream which contain the average fluctuation limit in zooplankton, phytoplankton, macro-zoobenthos and fishes is presented in Table 2.

The level of dominance of each plankton species is presented in Table 3. Zooplankton were represented by 4 species, chlorophyceae by 11 species, bacillariophyceae by 10 species and Myxophyceae by 6 species.

Qualitative analysis and level of dominance of the macro zoobenthic fauna is presented in Table 4. The most rich order of benthos was Trichptera with 6 species followed in decreasing order by
Diptera (5 species), Ephemeroptera (4 species), Coleoptera (3 species) and odonata (2 species). 
Table 1: Meteorological and ecological quality of river Pinder (1981-82)

\begin{tabular}{|l|l|l|}
\hline SN & Parameters & Fluctuation limit \\
\hline 1. & Transparency $(\mathrm{cm})$ & $12.0 \pm 2.0$ (Monsoon) - Clear up to the bottom \\
2. & Discharge of the stream $($ Cumec) & $28.0 \pm 2.0$ (Winter) $-320.0 \pm 65.0$ (monsoon) \\
3. & Current velocity $\left({\left.\mathrm{m} . \mathrm{sec}^{-1}\right)}\right)$ & $0.45 \pm 0.8$ (spring) $-1.76 \pm 0.45$ (monsoon) \\
4. & Water temperature $\left({ }^{\circ} \mathrm{C}\right)$ & $8.7 \pm 0.7$ (winter) $-17.5 \pm 1.3$ (summer) \\
5. & $\mathrm{pH}$ & $7.5 \pm 0.1$ (monsoon) $-8.3 \pm 0.1$ (monsoon) \\
6. & Turbidity $(\mathrm{JTU})$ & $25.0 \pm 1.0$ (winter) $-337.5 \pm 44.0$ (monsoon) \\
7. & Dissolved oxygen $\left(\mathrm{mg} . \mathrm{l}^{-1}\right)$ & $6.9 \pm 2.1$ (monsoon) $-12.6 \pm 0.8$ (spring \\
8. & Free $\mathrm{CO}_{2}\left(\mathrm{mg} . \mathrm{l}^{-1}\right)$ & Nil (winter) $-1.0 \pm 0.2$ (monsoon) \\
9. & Total alkalinity $\left(\mathrm{mg} . \mathrm{l}^{-1}\right)$ & $47.6 \pm 4.6$ (monsoon) $-74.4 \pm 5.6$ (winter) \\
\hline
\end{tabular}

Table 2: Biotic profile of river Pinder (1981-82)

\begin{tabular}{|c|c|c|}
\hline $\mathrm{SN}$ & Biota & Fluctuation limit \\
\hline 1. & Zooplamkton (units..$^{-1}$ ) & $172 \pm 52$ (monsoon)- $390 \pm 25$ (autumn) \\
\hline 2. & Phytoplankton (units. $1^{-1}$ ) & $1720 \pm 726$ (monsoon)- $7719 \pm 378$ (spring) \\
\hline 3. & Benthic Trichopterans (units. $\mathrm{m}^{-2}$ ) & $26.2 \pm 4.9$ (monsoon)- $140.2 \pm 21.9$ (summer) \\
\hline 4. & Benthic Ephemeropterans (units. $\mathrm{m}^{-2}$ ) & $14.2 \pm 6.5$ (monsoon) $-76.5 \pm 16.2$ (summer \\
\hline 5. & Benthic Plecopterans (units.m ${ }^{-2}$ ) & $5.6 \pm 1.8$ (monsoon) $-42.8 \pm 7.2($ summer $)$ \\
\hline 6. & Benthic Coleopterans (units. $\mathrm{m}^{-2}$ ) & $17.2 \pm 4.2($ monsoon $)-20.0 \pm 4.0$ (autumn) \\
\hline 7. & Fish species in catch $\left(\mathrm{SN}_{\mathrm{x}}\right)$ & $10 \pm 2$ (monsoon) $-20 \pm 4$ (autumn) \\
\hline
\end{tabular}


Table 3: Plankton species dominance river Pinder (1981-82)

\begin{tabular}{|c|c|c|c|}
\hline Biota & SN & Name of pecies & Level of dominance \\
\hline \multirow[t]{2}{*}{ Zooplankton (Crustaceans) } & 1 & Daphnia & Nil- Rare \\
\hline & 2 & Bosmina & Nil- Rare \\
\hline \multirow[t]{3}{*}{ Zooplankton (Rotifers) } & 3 & Cyclops & Nil- Rare \\
\hline & 4 & Brachionus & Nil- Rare \\
\hline & 5 & Keratella & Nil- Rare \\
\hline \multirow[t]{11}{*}{ Phytoplankton (Chlorophyceae) } & 6. & Spirogyra & Rare- Common \\
\hline & 7 & Ulothrix & Rare- Common \\
\hline & 8 & Cladophora & Common- Abundant \\
\hline & 9 & Oedogonium & Rare- Common \\
\hline & 10 & Hydrodictyon & Rare- Common \\
\hline & 11 & Zygnema & Rare- Common \\
\hline & 12 & Hildenbrandia & Nil- Rare \\
\hline & 13 & Dinobryon & Nil- Rare \\
\hline & 14 & Microspora & Nil- Rare \\
\hline & 15 & Tribonema & Nil- Rare \\
\hline & 16 & Ankistrodesmus & Nil- Rare \\
\hline \multirow[t]{10}{*}{ Phytoplankton (Bacillariophyceae) } & 17 & Navicula & Common - Abundant \\
\hline & 18 & Fragillaria & Common - Abundant \\
\hline & 19 & Cymbella & Common - Abundant \\
\hline & 20 & Synedra & Common - Abundant \\
\hline & 21 & Nitzschia & Common - Abundant \\
\hline & 22 & Diatoma & Rare- Common \\
\hline & 23 & Gomphonema & Rare- Common \\
\hline & 24 & Cocconeis & Rare- Common \\
\hline & 25 & Asterionella & Rare- Common \\
\hline & 26 & Cyclotella & Rare- Common \\
\hline \multirow[t]{6}{*}{ Phytoplankton (Cyanophyceae) } & 27 & Rivularia & Rare \\
\hline & 28 & Lyngbya & Rare \\
\hline & 29 & Anabena & Rare \\
\hline & 30 & Phormidium & Rare \\
\hline & 31 & Anacystis & Rare \\
\hline & 32 & Oscillatoria & Rare \\
\hline
\end{tabular}


Table 4: Macro-Zoobenthic species dominance river Pinder (1981-82)

\begin{tabular}{|l|l|l|l|}
\hline Biota & SN & Name of pecies & Level of dominance \\
\hline Order- Epemeroptera (Nymphs) & 1 & Caenis & Common \\
& 2 & Baetis & Common \\
Order- Plecoptera (Nymphs) & 3 & Ephemerella & Common \\
& 4 & Nemoura & Rare \\
Order- Coleoptera (Larvae) & 5 & Perla & Rare \\
& 6 & Isoperla & Rare \\
Order- Trichoptera (larvae) & 7 & Neoperla & Rare \\
& 8 & Psephenus & Common \\
& 9 & Promoresia & Rare \\
Order- Diptera (Larvae) & 10 & Hydrophilus & Common \\
& 11 & Hydropsyche & Common \\
& 12 & Stenopsyche & Rare \\
& 13 & Rhyacophila & Rare \\
Order- Odonata (Larvae) & 14 & Limnephilus & Rare \\
& 15 & Neophylax & Common \\
& 16 & Glossosoma & Common \\
& 17 & Chironomus & Common \\
& 18 & Simulium & Common \\
& 19 & Antocha & Rare \\
& 20 & Tipula & Rare \\
& 21 & Atherix & Rare \\
\hline
\end{tabular}

Dominance level of different fishes is presented in Table 5. Which indicates that there are 24 fish species belonging to 10 genera. The dominat family was Cyprinidae which was represented by 7 genera and 14 species. Family sissoridae was represented by 2 genera and 5 species while the family cobitidae by only 1 genera and 5 species. The overall catch composition of fishes in river in Pinder is represented in Fig 2. Which shows that the dominant fish catch was of Schizothoracine fishes $(78 \%)$ followed by Tor sps ( $8 \%)$, Garra and Crossocheilus (6\%) and other miscellaneous fishes (8\%) which included minor carps and loaches. It has been pointed out by the ecologists that the biotic and abiotic parameters are interdependent and any change in one of them is likely to produce significant change in other. Water temperature was noticed to be one of the main controlling factor, the so called driver in river Pinder which can be directly correlated to spawning requirement of Schizothoracids which form bulk of fishery in Pinder. Current velocity is another driver in Pinder which showed that during its maxima in winter the biotic population decreases while in winter and summer months it is minimum hence recorded population of entire biota is more. $\mathrm{pH}$ also has significant effect as it is low in monsoon when population is also low and high in winters when population is also high. Similar results were shown by Dobriyal and Singh $(1981,1988,1989)$ and Nautiyal (1985). 
Table 5: Level of dominance of fishes in the river Pinder (1981-82)

\begin{tabular}{|l|l|l|}
\hline SN & Fish species & Level of dominance \\
\hline & Family-Cyprinidae & \\
1. & Schizothorax sps (3) & Abundance \\
2. & Schizothoraichthys sps (1) & Common \\
3. & Tor sps (2) & Common \\
4. & Garra sps (2) & Common \\
5. & Crossocheilus sps (1) & Common \\
6. & Puntius sps (2) & Rare \\
7. & Barilius sps (3) & Common \\
& Family: Sissoridae & Common \\
8. & Glyptothorax sps (4) & Common \\
9. & Pseudecheneis sps (1) & \\
& Family- Cobitidae & Rare (Common in side waters) \\
10 & Noemacheilus sps (5) &
\end{tabular}

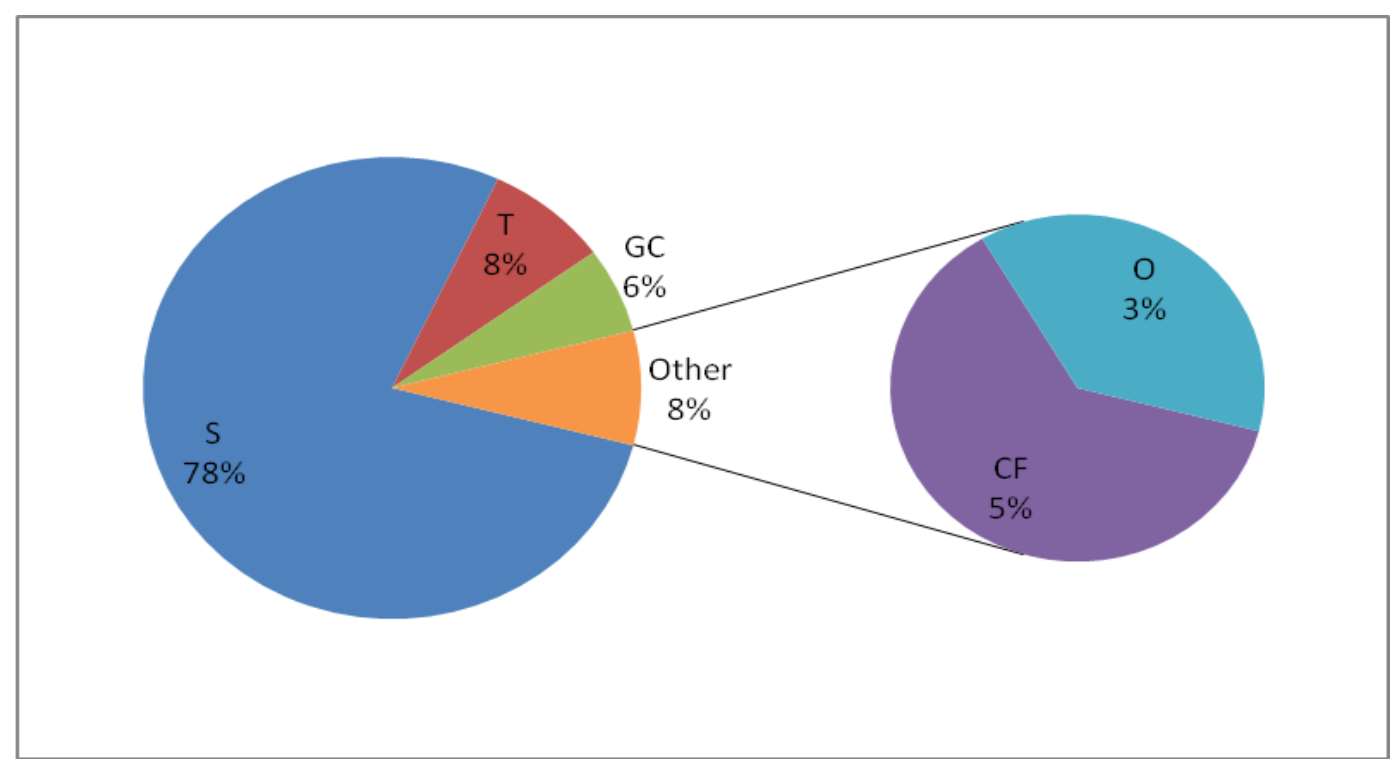

Fig 2: Average Fish catch composition in river Pinder during 1981-82 ( $\mathrm{S}=$ Schizothoracids, $\mathrm{T}=$ Tor $\mathrm{sps}$, $\mathrm{GC}=$ Garra-Crossocheilus sps, $\mathrm{CF}$ Catfishes, $\mathrm{O}=$ minor carps and loaches in side waters

Like other hillstreams, the fishery of Pinder is also influenced negatively by various anthropogenic activities. One of the important reasons for depletion in fishery is unscientific fishing techniques used by the village folk. The use of dynamite, ichthyo-toxic plants and electric fishing is highly disastrous. Conservation strategies must be enhanced to conserve fishery here by creating ecological awareness and safeguard of river banks through afforestation. Pinder is the best habitat to establish snow trout hatchery in Uttarakhand.

\section{References}

Badola, S.P. and Singh, H.R.(1981). Hydrobiology of river Alaknanda of the Garhwal Himalaya. Indian J. Ecol. 8 : 269- 276. 
Balodi, V.P., Dobriyal, A.K., Joshi, H.K., Uniyal, S.P. and Thapliyal, A. 2004. Epilithic periphyton and detritus ecology of the springfed stream Eastern Nayar in Garhwal Himalaya. Environmental Conservation Journal. 5 (1-3): 1-5

Bahuguna, P and A K Dobriyal, A K (2018). First report on the occurrence of some benthic macroinvertebrates in the spring-fed streams of Garhwal Himalaya, India. International Journal of Research and Analytical Research and Analytical Reviews .E-SSIN 2348-1269, P ISSN 2349- $\quad 5138$ Vol 5 (4): 437-443

Bisht, K.L, Dobriyal, A.K., Bisht, M.S., Joshi,H. and Singh, H.R. 2005. Fisheries ecology of the high altitude river Pinder from Garhwal Himalaya. Biological Diversity in Freshwater Environments (Ed.) Nautiyal, P, Bhatt, J.P., Gusain, O.P. and Dobriyal, A.K. Transmedia, Srinagar Garhwal: 242-248.

Day, F. (1889). The fishes of British India, including Ceylone and Burma, Taylor and Francis London pp 509.

Dobriyal, A.K.(1985). Ecology of limnofauna in the small stream and their importance to the village life in Garhwal Himalayas. Uttar Pradesh J. Zool. 5 (2) : 139-144.

Dobriyal, A.K. (1991). An appraisal of the fishery resource of riverine ecosystems of Garhwal, Central Himalaya. In : Bhatt, S.D. and Pandey, R.K. (Ed.) . Ecology of Mountain waters. Ashish Publishing House, New Delhi. Pp. 306- 312.

Dobriyal, A.K. 2003. Structure and function of an ecosystem with special reference to river Nayar. National symposium on ecology and aquatic biodiversity (SEBAE), 15-17 February,2003. extended Abstract No 86 : pp $1-4$.

Dobriyal, A.K. (2006). Ecological studies on the biodiversity of river Khoh in the foot hill of Garhwal Himalaya. Part II: macrozoobenthic analysis. Aquacult. Vol. 7(2) : 277-283.

Dobriyal, A.K. , Singh, H.R. and Bisht, K.L. 1983. Diurnal variation in hydrobiological parameters of two hillstreams of Garhwal
Himalaya,India. Uttar Pradesh J. Zool. 3 : 3034.

Dobriyal, A.K. and Joshi, H.1999. Faunal diversity and its determinant factors in some hillstreams of Garhwal Himalaya. Uttar Pradesh J. Zool. 19 (1): 85-87.

Dobriyal, A.K. and Kotnala, C.B. 1993. Primary productivity of periphyton in the river Eastern Nayar at Satpuli, Pauri Garhwal. Bioved, 4 : 267-268.

Dobriyal, A.K. and Kotnala, C.B. (2005). Primary productivity of the spring-fed river Nayar (Garhwal Himalaya, Uttaranchal). In : Nautiyal, P. et.al. (Ed.): Biological Diversity in freshwater environments. Transmedia Srinagar Garhwal. Pp 96-107.

Dobriyal, A.K. and Kumar, N. (1988). Fish and fisheries of the river Mandakini. In : Khulbe, R.D. (Ed). Prospectives in aquatic biology. Papyrus publishing house. New Delhi. pp. 337-340.

Dobriyal, A.K. and Singh, H.R. (1981). Diurnal variation in some aspects of limnology of the river Mandakini from the Garhwal Himalaya U.P. Uttar pradesh. J. Zool. 1 : 16-18.

Dobriyal, A.K. and Singh, H.R. 1987. A case study on the origin of rhithroplankton in the Garhwal hillstreams. Agri. Biol. Res. 3: 104- 106.

Dobriyal, A.K. and Singh, H.R. (1988). Ecological basis for ichthyofaunal variation in two hillstream of Garhwal Himalaya. pp.313317. Ini Joseph M.M. (ED). The First Indian fisheries forum Proceedings. Ashian Fisheries society Indian Branch Mangalore. Pp. 313317

Dobriyal, A.K. and Singh, H.R. 1989. Observations on temporal trends of phytoplankton diversity in the river nayar of Garhwal Himalaya. J. Freshwater Biol. 1: 16.

Dobriyal, A.K. Bahuguna, A.K.,Kotnala, C.B. Kumar, N. and Singh, H.R. (1992). Preliminary observations on seasonal trends in macro-zoobenthic diversity in the river Nayar of Garhwal Himalaya. In K.L. Sehgal (Ed) 
Recent researches in coldwater Fisheries. pp. 119-127.

Dobriyal, A.K., Balodi, V.P., Kumar, N. and Bisht, M.S. 2002. An appraisal of the fishery potential of river Nayar with a note on its improvement possibilities. Coldwater fish genetic resources and their conservation. Nature Conservator Publication No. 7. pp. 235-242.

Dobriyal, A.K., Kumar, N., Kotnala, C.B., Bahuguna, A.K. and Singh, H.R. 1991. Preliminary observations on seasonal trends in macrozoobenthic diversity in the river Nayar of Garhwal Himalaya. In : Sehgal, K. L. ( Ed.) : Recent researches in Coldwater Fisheries. Pp. 119- 127.

Dobriyal, A.K., Bahuguna, A.K. Kumar, N. and Kotnala,C.B.1993. Ecology and seasonal diversity of plankton in a spring-fed stream Khanda gad of Garhwal Himalaya. In Singh, H.R. (Ed.) Advances in Limnology. NPH, New Delhi pp. 175-180.

Dobriyal, A.K., Kotnala, C.B., Kumar, N. and Balodi, V.P. 1999. Density and primary productivity of periphyton correlated with physico- chemical parameters in the river Western Nayar of Garhwal, Cental Himalaya, India. Advances in Biosciences. 18 (2) : 35 44.

Dobriyal, A.K., Balodhi, V P, Joshi, H.K., Thapliyal, A., Bahuguna, P., Uniyal, S.P. and Kotnala, C B. 2009. Substratum heterogeneity and indicator macro-zoobenthos of the Eastern Nayar, Garhwal, Central Himalaya. $J$. Mountain Res. 4: 130-135

Dobriyal, A.K., Balodi, V P, Joshi, H.K., Bahuguna, P. and Kumar, N. (2011). Seasonal cyclicity of Macrozoobenthos correlated with detrimental abiotic factors in the Eastern Nayar of Garhwal Himalaya, Uttarakhand. In: Himalayan Aquatic Biodiversity Conservation and new tools in Biotechnology (Eds.J P Bhatt, Madhu Thapliyal and Ashish Thapliyal). Transmedia Publication Srinagar Garhwal PP. 94-103

Dobriyal, K. and Dobriyal, A K (2015).Fish environment of Garhwal Himalaya- A socio- economic, religious and Cultural analysis. Journal of Environmental and SocialSciences: 2 (1): pp 1-3

Goswami, S and Dobriyal, A K (2018). Spatial distribution and diversity of fishes in different ecological sections of spring fed river Mandal from Uttarakhand, India. International Journal of Recent Scientific Research. 9 (12): 29958-29962

Gusain, O.P. and Gusain, M.P. (2005) Caddis (Trichoptera) larvae of a spring fed stream in Garhwal Himalaya. In: Nautiyal, P. et.al. (eds.) Biological diversity of fishwater environments. pp:249-261 Transmedia (Srinagar). Uttranchal, India.

Katoch, P.D., V.P. Balodi, A. Thapliyal, Koshal Kumar, Md. Rashid, Md. Sagir and A.K.Dobriyal (2015). Population structure and diversity analysis of benthic Ephemeropterans in Western Nayar river during 2014-15, Journal of Mountain Research, Vol. 10, pp 55-66.

Khanna, D.R., Badola, S.P. and Dobriyal, A.K. 1993. Plankton ecology of the river Ganga at Chandighat, Hardwar. In : Singh, H.R. (Ed.) Advances in Limnology. NPH, Delhi. Pp. 171-174

Khanna, D.R., Badola, S.P., Singh, H.R. and Dobriyal, A.K. 1992. Observations on seasonal trends in diatomic diversity in the river Ganga at Saptsarovar, Hardwar. In : Sehgal, K.L. (Ed.) Recent Researches in Coldwater Fisheries. Today and Tommorrow Printers and Publishers, New Delhi pp. 99107.

Koshal Kumar, Anita Rawat Rana C.B. Kotnala, V.P. Balodi And A.K. Dobriyal (2016) . Water Quality And Pollution Status Of Rawasan Stream In Garhwal Himalaya, Uttarakhand, India. J Mountain Res 11: 9-14 (ISSN -9743030)

Kumar, N. and Dobriyal, A.K. 1992. Some observations on water mites of a hillstream Khandagad in Garhwal Himalaya. $J$. Freshwater Biol. 4: 193-197.

Kumar, N. and Dobriyal, A.K. 1996. Benthic diversity of Garhwal Himalayan hillstrteams 
in relation to their fishery potential. In: Joseph, M.M. (Ed.) The Third Indian Fisheries Forum Proceedings.159-162.

Kumar, N and Dobriyal, A.K. 1999. Correlation of some environmental variables with adaptivenet spinning strategies in stream larval hydropsychids (Trichoptera) in Garhwal Himalaya. Tropical Freshwater Biology, Nigeria. $8: 27-30$

Kumar, K., Rautela, K.K., Bisht, K.L., Joshi, V.D., Rautela, A.S. and Dobriyal, A.K. (2006) Ecological studies on the Biodiversity of river Khoh in the foothills of Garhwal Himalaya: Part I: Phytoplankton analysis. J. Natcon, 18 (1): pp 71-80.

Nautiyal, P. (1885). Studies on the riverine ecology of torrential waters in the Indian uplands of Garhwal region. I. Seasonal variation in percentage occurrence of planktonic algae. Uttar Pradesh J. Zool. 5: 14-19.

Nautiyal, P., Shivam, A., Rawat, G. Singh. K.R., Verma, J and Dwivedi, A.C. (2004) Longitudinal variation on the structure of Benthic communities in the upland Vindhyan and Himalayan River: River continuum concept approach. Natl. J. Life Sci. Vol (I) : 85-88.

Rautela, Negi, K S , Bisht, K.L., Joshi, V D, Rautela, A S., Kumar, K and Dobriyal, A.K. 2009. Correlative analysis of some detrimental factors with ovarian maturity in three hillstream fishes. J. Mountain Res. 4: 158-162

Sagir, M, Rashid M, Dobriyal A K (2018). Influence of riparian vegetation on the detritus standing stock in the river Western Nayar of Garhwal Himalaya. International Journal of Research and Analytical Research and Analytical Reviews (IJRAR).E-SSIN 23481269, P ISSN- 2349-5138, Vol 5 (4): 10511064.

Sharma, R.C. (1991). Rhithronology of Bhagirathi, Garhwal Himalaya, India. In : Pandey, R.K., Bhatt, S.D. and Panda, R.K. (Ed) Ecology of the mountain waters. Ashish
Publishing House. Punjabi bagh, New Delhi pp. 124-137.

Singh, H.R., Dobriyal, A. K.and Nauriyal, B. P. 1985. Spawning patterns and environmental regulation of spawning in hillstream fishes. In: The Endocrine System and the Environment (Ed.) Follett, B.K.et.al. Japan Sci. Soc. Press. Tokyo Springer- Verlag, Berlin. Pp.1- 11.

Ward, H.B. and Whiplle, G.V. (1966). Freshwater biology (ED: W T Edmundson).John wiley and Sons, Inc, New York., pp. 1203.

Welch, P.S. (1948). Limnological Methods. Mc Graw- Hill Book Co. NY, Toronto, London.

Welch, P.S. (1952). Limnology. Mc Graw- Hill Book Co. NY, Toronto, London. 538 pp. 